\title{
Device Fracture Problem
}

National Cancer Institute

\section{Source}

National Cancer Institute. Device Fracture Problem. NCI Thesaurus. Code C92055.

Problems caused by the separation of a component, object, or material into two or more pieces including shear. 